\title{
REGULATION OF THE LEGALITY OF MICRO, SMALL AND MEDIUM ENTERPRISES THROUGH THE ONLINE SINGLE SUBMISSION SYSTEM TO INCREASE COMPETITIVENESS
}

\author{
Amin Purnawan \\ Sultan Agung Islamic University \\ amin.p@unissula.ac.id \\ Siti Ummu Adillah \\ Sultan Agung Islamic University \\ ummu@unissula.ac.id
}

\begin{abstract}
The purpose of this paper is to review the regulation of the legality of micro, small, and medium enterprises (MSMEs) through the Online Single Submission System (OSS) to increase competitiveness, as well as to analyze barriers and solutions. The research method used an empirical juridical approach, the collected data were analyzed by descriptive analysis. The results showed that the problematic implementation of the regulation of MSME business legality registration through the OSS System was mainly due to the lack of socialization and education to MSME entrepreneurs regarding the obligation to register permits through OSS. This affects the compliance of MSMEs in processing their business permits. The solutions that need to be done include increasing the socialization of Integrated Electronic Business Licensing Services/Online Single Submission. MSME players need to be empowered through human resource development, capital support, production and productivity, business protection, partnership development, business networks and marketing as well as business legality, especially registration of business licenses through the Integrated Electronic Business Licensing Service.
\end{abstract}

Keywords: Business, Legality, Registration.

\section{A. INTRODUCTION}

In the era of the industrial revolution 4.0, the presence of MSMEs is increasingly needed. The role of the state is to provide an effective regulatory framework along with mechanisms for oversight and law enforcement. The government must consider the fact that support for the legality aspect is very much needed for MSME actors where low-income workers are present. The incentives imposed can be determined by considering the relevant standards, because the capacity of MSMEs is limited, both in terms of acceptance and the technology used. ${ }^{1}$ This writing will analyze the implementation of MSME business registration as well as obstacles and solutions.

1 Arijanto, A., Pembiayaan Sektor Usaha Kecil Menengah. Modul ke 11 Perekonomian Indonesia. Pusat Pengembangan Bahan Ajar-UMB, tanpa tahun. 
Based on the map of the strength of MSMEs in Indonesia, MSMEs are one of the pillars in the economy that are resilient to economic shocks and have many business fields that can be developed. On the other hand, there are several weaknesses that constrain the development of MSMEs apart from capital, namely intellectual capital, management capabilities, innovation capabilities, entrepreneurship, production and operations, marketing, including customer relationship management and legal. ${ }^{2}$

Law can function as a social engineering tool (law is a tool of social engineering). So through the politics of business legality law, MSME growth can be encouraged, and if managed properly, MSMEs can increase productivity, increase people's income and contribute to regional income. Even though MSMEs have a very large contribution in supporting the national economy, this is not necessarily followed by an increase in income. The lack of improvement in the business climate and the existence of policies on them are interesting things to research and study so that solutions can be found academically and implementatively.

Theoretically, in government administration, rules or guidelines are needed to provide direction for the implementation of the authority of administrative officials, so that the actions of administrative officials in addition to realizing the principle of equality can also be guaranteed legality. ${ }^{3}$

This research is related to science and technology because it will enrich knowledge in the field of law, especially aspects of licensing and trademarks. The research also supports the implementation of the Research Master Plan (RIP) of the Unissula Semarang Research Institute to participate in developing small and medium enterprises, especially in Central Java, from legal aspects, human resources, marketing, production finance, innovation and technology, ICT to be able to produce optimal performance. and able to have competitiveness both locally, nationally and internationally. With the existence of high-performing MSMEs, it will boost the economy of the people of Semarang City, increase employment and reduce poverty levels. ${ }^{4}$

MSMEs as major economic actors at the national, regional and local levels have an important and strategic role in creating jobs, alleviating poverty and encouraging growth in the value of non-oil and gas exports. However, MSMEs still have several obstacles both internally and externally in order to be competitive. The internal constraints can be in the form of limited capital, difficulty in raw materials, low production capacity and product

2 Amin Purnawan, Rekonstruksi Sistem Pemungutan Pajak Penghasilan (PPh) Badan Berbasis Nilai Keadilan. Jurnal Dinamika Hukum Terakreditasi, ISSN 1410-0797, Vol. 11 Edisi Khusus Februari. 2011

3 Rakhmat Bowo Suharto, Regulation Urgency Concerning Administrative Sanction Guidelines In Space Administration, Jurnal Pembaharuan Hukum, Vol. VI No.3, September-Desember, 2019, page. 330.

4 Siyamtinah dan Eni Rahmani, Model Pengembangan Green Business untuk Peningkatan Kinerja Keuangan dan Kinerja Pasar, Laporan Penelitian Hibah Bersaing Dikti, 2012. 
quality, and weak market access, while external constraints that are deemed to hinder the development of MSMEs are the threat of foreign products. ${ }^{5}$

MSMEs are a solution for the government to reduce poverty and unemployment. There are around 48 million MSMEs that are operating and can support their families. Many parties pay attention to this UMKM. In fact, developed countries have started businesses with MSMEs. ${ }^{6}$

Each member of society as a role holder is determined by his role by the role expected of him, both by legal norms and by forces outside the law. ${ }^{7}$ Legality aspects that take into account the interests of the business world need to be used as a new paradigm. With globalization and structural change policies, Micro, Small and Medium Enterprises (MSMEs) are increasingly needed. The role of the state is to provide an effective regulatory framework along with monitoring and enforcement mechanisms.

Poverty is a chronic problem that afflicts the Indonesian nation. Based on the Microcredit Summit report in 2002, the number of world population living below the poverty line is estimated at around 235 million families, some of which, namely 157.8 million (67\%) are in Asian countries. One of the efforts to reduce poverty is by breaking the poverty chain through empowering groups of people who have businesses in the smallest sector (UKM). ${ }^{8}$

Business legality includes several aspects that must be fulfilled, including: deed of establishment, company name, trademark, Trade Business Registration Certificate (TDUP) and Trade Business License (SIUP), Taxpayer Identification Number (NPWP), Business Place Permit, Obligatory List of Companies (WDP).

Completeness of the legality aspects of MSME businesses is very important in creating legal certainty that can support performance and sustainable competitive advantage, especially micro, small and medium enterprises. Success in managing the legality aspects, organizational knowledge assets, customer relationship management, and innovation capability will have an impact on the competitive advantage of MSMEs.

\section{B. RESEARCH METHOD}

In general, this research is a descriptive analysis using a policy approach. The policy analysis approach examines the philosophical, sociological and juridical aspects of business legality law politics for MSMEs. Each of the approaches to these aspects will be used at a different level of research depth. Data were collected through interviews using a closed questionnaire which was submitted to MSME entrepreneurs in Semarang

5 Heru Sulistyo, Siyamtinah, Eni Rahmani, Model Peningkatan Kapabilitas Inovasi Dalam Rangka Meningkatkan Kinerja UKM Di Kota Semarang, Laporan Penelitian Hibah Bersaing Dikti Tahun kedua, 2011.

6 Adler Haymans Manurung, Modal untuk Bisnis UKM, Gramedia, Jakarta, 2008, page. 9.

7 Satjipto Rahardjo, Hukum dan Masyarakat, Penerbit Angkasa, Bandung. 1990, page. 29.

8 Euis Amalia, Keadilan Distributif dalam Ekonomi Islam Penguatan Peran LKM dan UKM di Indonesia, Raja Grafindo Persada, Jakarta, 2009, page. 2. 
City. The selection of respondents was carried out by means of accident sampling (those we encountered), namely the UMKM entrepreneurs. The number of respondents was 30 entrepreneurs. considering that this amount is sufficient for statistical analysis. Collecting data in this way is intended to determine the characteristics and aspirations of MSME actors regarding the obligation to fulfill business legality registration.

The research methods and techniques used are a combination of literature studies, field observations, survey methods with structured interviews, and in-depth interviews.

Interviews through open questionnaires that are submitted to key figures who understand the legality of MSME businesses and businesses. Unlike the closed questionnaire, this interview is conducted to explore problems in more depth in order to find the most basic problems among other problems. This data collection is also intended to find out alternative solutions for solving problems in the implementation of business legality registration for MSMEs through the OSS system in Semarang City.

\section{RESULTS AND DISCUSSION}

\section{Understanding UMKM about Business Legality Registration in Semarang City}

Micro, Small and Medium Enterprises, hereinafter abbreviated as UMKM, are productive economic enterprises based on business scale according to statutory regulations. ${ }^{9}$ Micro Enterprises are productive businesses owned by individuals and/or individual business entities that meet the criteria of Micro Enterprises.

Small Business is a productive economic business that stands alone, which is carried out by an individual or a business entity that is not a subsidiary or branch of a company that is owned, controlled, or is a part, either directly or indirectly, of a Medium or Large Business that meets the criteria of a Business. Small.

Medium Enterprises are productive economic enterprises that are independent, carried out by individuals or business entities that are not subsidiaries or branches of companies that are owned, controlled, or are part of, either directly or indirectly, with Small or Large Businesses with total net assets or annual sales proceeds as regulated in a Regional Regulation.

Large Business is a productive economic business undertaken by a business entity with a net worth or annual sales proceeds greater than that of a Medium Enterprise, which includes state-owned or private national businesses, joint ventures, and foreign businesses that carry out economic activities in Indonesia.

Electronically Integrated Business Licensing or Online Single Submission, hereinafter abbreviated as OSS, is a Business License issued by the OSS Institution for and on behalf of the minister, head of institution, governor or regent/mayor to business actors through an

9 Undang-undang Nomor 20 Tahun 2008 tentang Usaha Mikro, Kecil dan Menengah. 
integrated electronic system. The objectives of the issuance of IUMK are: 1) To obtain certainty and protection in doing business in a predetermined location; 2) Get assistance for business development; 3) Get easy access to finance to bank and non-bank financial institutions; 4) Get easy empowerment from the central government, local governments and / or other institutions. ${ }^{10}$

In this study, 30 MSME actors in Semarang were used, namely respondents who filled out the questionnaire correctly and provided reliable information.

The education level of the respondents who graduated from junior high school was 7 people $(23.3 \%), 12$ people graduated from high school $(40.0 \%), 5$ graduates $(16.7 \%)$ of graduates, Others, namely SD education amounted to 5 people $(16.7 \%)$, and Diploma amounting to 1 person (3.3\%). Based on the level of education, respondents have the ability to understand and answer the questionnaire well.

The duration of the UMKM business consists of $<5$ years, totaling 4 people $(13.3 \%)$, the length of the business is between $5-<10$ years and $10-<15$ years, each amounting to 9 people (30\%). There are 8 MSMEs with a business length of 15 years or more (26.7\%). When viewed from the length of the MSME business, the data shows that most of them are between 5-15 years or $60 \%$. This shows that MSMEs are in a period of business growth, and have sufficient resistance to face competition in the business world.

The number of employees working at MSMEs, as many as 1-4 people, totals 9 MSMEs (29\%, 5-19 people totaling 19 MSMEs (61.3\%). The number of employees is $20-25$ people totaling 2 MSMEs (6.5\%). The number of employees working at MSMEs is mostly 5-19 people, which shows that MSMEs are proven to be able to absorb quite a lot of jobs so that they can reduce unemployment.

The assets of MSME assets currently, less than 50 million, amount to 4 people $(12.9 \%),>50$ million to 500 million, amounting to 20 people $(64.5 \%),>500$ million to 10 billion totaling 6 people $(19.4 \%)$. If seen from the assets of the MSME companies which are currently respondents, most of them are $>50$ million to 500 million, which is a fairly large number of assets, and shows a fairly good ability to develop assets.

The sales turnover of MSMEs every year, less than 300 million is 13 people (41.9\%), a turnover of 300 million to 2.5 billion is 16 people $(51.6 \%)$, and a turnover of 2.5 billion to 50 billion is 1 person $(3,2 \%)$. When viewed from the sales turnover of MSME companies, most of them amounted to 300 million to 2.5 billion (53.3\%) and less than 500 million $(43.3 \%)$, this shows that the potential for MSMEs is quite large in driving the economy.

10 Amin Purnawan, Akhmad Khisni, Siti Ummu Adillah, Penyuluhan Hukum Pendaftaran Izin Usaha Mikro Kecil (IUMK) di Kota Semarang melalui Sistem Online Single Submission (OSS), Indonesian Journal of Community Services, Vol. 2, No. 1, 2020, page. 3. 
Respondents' Knowledge of Government Regulation Number 24 of 2018 concerning Integrated Business Licensing Services Electronically/Online Single Submission, all respondents answered they did not know, namely 30 people (100\%).

The number of employees working at MSMEs, as many as 1-4 people, totals 9 MSMEs (29\%, 5-19 people totaling 19 MSMEs (61.3\%). The number of employees is $20-25$ people totaling 2 MSMEs (6.5\%). The number of employees working at MSMEs is mostly 5-19 people, which shows that MSMEs are proven to be able to absorb quite a lot of jobs so that they can reduce unemployment.

The assets of MSME assets currently, less than 50 million, amount to 4 people $(12.9 \%),>50$ million to 500 million, amounting to 20 people $(64.5 \%),>500$ million to 10 billion totaling 6 people $(19.4 \%)$. If seen from the assets of the MSME companies which are currently respondents, most of them are $>50$ million to 500 million, which is a fairly large number of assets, and shows a fairly good ability to develop assets.

The sales turnover of MSMEs every year, less than 300 million is 13 people (41.9\%), a turnover of 300 million to 2.5 billion is 16 people $(51.6 \%)$, and a turnover of 2.5 billion to 50 billion is 1 person $(3,2 \%)$. When viewed from the sales turnover of MSME companies, most of them amounted to 300 million to 2.5 billion (53.3\%) and less than 500 million $(43.3 \%)$, this shows that the potential for MSMEs is quite large in driving the economy.

Respondents' Knowledge of Government Regulation Number 24 of 2018 concerning Integrated Business Licensing Services Electronically/Online Single Submission, all respondents answered they did not know, namely 30 people (100\%).

Respondents' Knowledge of KUKM Ministerial Regulation Number 02 of 2019 concerning Electronically Integrated Business Licensing, all respondents answered they did not know, namely 30 people $(100 \%)$.

Respondents do not know that the Business Identification Number (NIB) is the identity of the Online Single Submission. All respondents answered that they did not know, amounting to 30 people $(100 \%)$. All respondents $(100 \%)$ do not know that the Business Identification Number (NIB) is the identity of the Online Single Submission.

Respondents do not know the Company Registration Certificate (TDP) is a letter of approval provided by the Online Single Submission Institution for MSME Players who have registered. Respondents who answered don't know were 30 people (100\%). All respondents (100\%) do not know that the Company Registration Certificate (TDP) is a letter of ratification given by the Online Single Submission Institute for MSME Players who have registered.

Regarding questions about how to apply for a Micro and Small Business Permit (IUMK) through the OSS institution, all respondents answered they did not know, totaling 30 people (100\%). All respondents 
$(100 \%)$ do not know how to apply for a Micro and Small Business License (IUMK) through the OSS institution.

Related to problems in registering business licenses for MSMEs through the OSS system, 10 respondents (33.3\%) answered that there was a lack of socialization/counseling. Respondents who answered with less socialization and less knowledge of information technology/internet were 19 (63.3\%). Respondents who answered with less socialization, had a business license that was not very important, and did not know enough about information technology/internet (3.3\%).

The expectations of UMKM players for the government with having business legality, respondents who answered: The government provides easy access to funds (interest-free funding); The government assists in the marketing of UMKM products; The government conducts outreach; Do not increase the price of soybean raw materials, and pay attention to MSMEs.

Suggestions for the government from MSME owners relating to the legality of MSME businesses, respondents answered: Need to improve service, quality and responsibility of the management institution; Need Funds Assistance; Protecting MSMEs from big investor competition; Give awards to UMKM; It is necessary to provide good raw materials for UMKM entrepreneurs; socialization and control of illegal fund levies; as well as visiting small entrepreneurs/giving attention.

Respondents of MSME actors who wish to have a permit/legality in their business who answered Yes were 17 people $(56.7 \%)$. Respondents who answered No were 7 people (23.3\%). Respondents who answered already had 6 people (20.0\%).

Factors that influence MSME actors having business permits/legality, according to respondents, are: Due to obeying laws; Fear of being penalized; Awareness of the benefits of business legality for MSMEs; and Make it easier to get financial assistance.

The factors that influence MSME actors not having a business license/legality, according to respondents, are: Not knowing if there is an obligation to take care of a business permit (legality); Don't know how to take care of a permit; Concern that there is a tax burden or other costs; and the business is still small/turnover is still small. Most of the respondents stated that the factors that influence the owners of MSMEs not having a business license are because their business is still small and they are worried that there will be tax burdens or costs that will arise from having a business license. This can occur due to lack of socialization and education to them.

\section{Problems and Solutions for MSME Legality Registration through the OSS System to Increase Competitiveness}

Micro, small and medium enterprises (UMKM) have complained about problems related to the online single submission, to obtain a Business Identification Number (NIB). This was conveyed by MSME 
actors to the Investment Coordinating Board (BKPM) at a meeting with the UMKM community in Semarang City.

The BKPM Director of Licensing and Non-Licensing Standardization Cooperation Indra Darmawan said that UMKM is one of the important components that must be of concern. "So, we have found a lot of those who previously found it difficult first, it turns out that after being directly guided technically it turns out to be possible and easy," he said in a press release, Tuesday (4/12/2019).

According to Indra, the policy of simplifying licensing by the government has continued to improve from 47 days to 3 hours. Then with this OSS revolution, it is expected that licensing arrangements will only take half an hour. During the meeting, the Semarang UMKM community submitted a number of complaints to the BKPM. Starting from the addition of business fields in the OSS system, to the issue of Intellectual Property Rights (IPR) which is considered to be the biggest weakness of domestic MSMES. BKPM will continue to disseminate OSS to all entrepreneurs in the regions. This is done as a government effort to simplify licensing services, which is marked by the issuance of Government Regulation Number 24 of 2018 concerning Electronically Integrated Business Licensing Services or also commonly known as Online Single Submission. ${ }^{11}$

The Regional Autonomy Monitoring Committee (KPPOD) still finds a number of problems with the Electronic-Based Integrated Licensing Service System or Online Single Submission in several regions and centers. From the results of the study, there are three aspects that play a role in the success or failure of OSS implementation, namely regulations, systems, and management. ${ }^{12}$

In the regulatory aspect at the center, Norms, Standards, Procedures, and Criteria or sectoral NSPK, which ideally serve as technical guidelines for permit services, do not concretely translate PP Number 24 of 2018 concerning OSS into procedures that are easy to follow. For example, to obtain an Industrial Business License (IUI), business actors are required to register again on the application. Even though PP 24/2018 clearly does not require this. The implication is that there are various variations in the SOP for permit services in various regions.

Apart from the NSPK, OSS mistakes are also reflected in the disharmony issue of PP 24 of 2018 with Law Number 15 of 2017 concerning Investment and Law Number 23 of 2014 concerning Regional Government. Where, disharmony here relates to the authority to give permits that previously were in the hands of the regional head now transferred to the OSS institution.

11 https://www.republika.co.id/berita/ekonomi/korporasi/18/12/04/pj6zx3383-pelaku-umkmmasih-sulit-mengakses-oss, akses 13-10-2019

12 https://www.merdeka.com/uang/peneliti-temukan-3-hambatan-pelaksanaan-online-singlesubmission.html 
Meanwhile, on the system aspect, according to Boedi from KPPOD, one of the weaknesses of the OSS system is the feature of determining business locations that is not synchronized with the Regional Spatial Plan (RTRW), as well as the availability of a Detailed Spatial Plan (RDTR). This could have implications for the establishment of business locations that are not in accordance with regional planning as stipulated in the RTRW document, or even not based on the location of allotment blocks and land parcels due to the absence of RDTR.

Finally, in the aspect of governance, OSS is still facing obstacles, both at the central and regional levels. At the central level, the OSS system is not yet fully integrated with the licensing system of the Ministry of Institutions. Meanwhile, in the regions, there are still many regional governments that have application-based independent regional licensing systems (through PTSP) that are not yet integrated with OSS institutions. $^{13}$

In order to accelerate the Micro and Small Business License (IUMK) process, the government issued Government Regulation Number 24 of 2018 concerning Electronically Integrated Business Licensing Services. To follow up on the PP, the Ministry of Cooperatives and SMEs issued two Ministerial Regulations, namely Ministerial Regulation Number 11 of 2018 concerning Cooperative Savings and Loan Business Licensing and Ministerial Regulation Number 02 of 2019 concerning Electronically Integrated Business Licensing for Micro and Small Enterprises.

Some of the MSME actors still do not have the awareness to take care of business legality. Local governments need to increase outreach to MSME players so that awareness and compliance will grow in starting a business by arranging business permits. The factors that influence the policy of MSME business legality management include:

a. MSME actors lack awareness regarding the legality of their business, so local governments need to be more proactive in providing outreach.

b. The number of levies outside of taxes as a social cost or security cost. In order not to create a burden that is too heavy for MSME actors, it is necessary to review the various existing levies.

c. Human resources for business legality service officers who are not yet competent and professional need to continue to increase the capacity of human resources.

d. Inadequate facilities and infrastructure for licensing management services need to be completed.

e. Weak enforcement of Perda (local law enforcement officers who are minimal in quality and quantity), so that there is a need for guidance.

According to most respondents, the government needs to regulate the legality aspects of MSME businesses because business licenses are

13 http://www.neraca.co.id/article/117460/ukm-dapat-kemudahan-izin-usaha-melalui-oss 
important for fostering and encouraging the growth and competitiveness of MSMEs. Socialization or counseling is very much needed by MSME actors, because so far they consider that there are very few and even have never received counseling on aspects of business legality. The hope is that with counseling it can increase taxpayer compliance in managing business legality.

The factors and variables that influence the policy of regulating business legality for MSMEs are: a strong government commitment (political will) to encourage the growth of MSMEs through justice-based regulations. UMKM players have the awareness of having a business license, but with the hope that there will be guidance from the government to encourage the growth of MSMEs, for example in the form of providing capital, training, skills, intensive coaching. Besides that, for MSMEs who are not disciplined in managing business legality, it is necessary to take firm action, so that there will be a growing awareness that having business legality is for the benefit of developing MSMEs. Meanwhile, MSMEs who are obedient in managing business legality can be given incentives and facilitation. To increase the awareness of UMKM players in managing business legality, socialization activities need to be continuously improved.

The results of this study indicate that MSME actors have an awareness of managing business legality in the hope that it is carried out fairly according to the ability of MSMEs. Development of future business legality regulatory designs needs to consider the ability to pay and the benefit principle for MSMEs.

The formulation of a business legality policy design in an effort to encourage the growth of MSMEs must be segmentative according to the level of capacity of MSMEs if necessary, free of charge. Different treatment in terms of obligations and benefits obtained by MSMEs is a necessity which is a social obligation of the state and society in general. ${ }^{14}$

MSMEs as the majority economic actors at the national, regional and local levels have an interest and strategic role in creating jobs, alleviating poverty and encouraging growth in the value of non-oil and gas exports. However, MSMEs still have several obstacles both internally and externally in order to compete. Internal constraints can include limited capital, difficulty in raw materials, low capacity and product quality, and weak market access. While the external obstacle that hinders the development of MSMEs is the threat of foreign products, therefore it is necessary to empower MSMEs, especially in facing competition in the era of the ASEAN Economic Community (AEC). ${ }^{15}$

14 Amin Purnawan, Siti Ummu Adillah, Problematika Plaksanaan Pendaftaran Legalitas Usaha UMKM melalui Sistem Online Single Submission (OSS) di Kota Semarang, Laporan Penelitian Kompetitif Unissula, 2019.

15 Amin Purnawan, Kami Hartono, 2017, Development of UMKM through Strengthening Aspect of Business Legality (Case Study of Weaving Industry in Central Java), International Journal of Applied Business and Economic Research, Vol. 15 (24), page. 422-423. 
The solutions that need to be done are as follows: 1$)$ Increase the socialization of Law no. 20 of 2008 concerning UMKM and Perda No. 13 of 2013 concerning Empowerment of MSMEs; Government Regulation Number 24 of 2018 concerning Integrated Electronic Business Licensing Services/Online Single Submission (OSS), 2) Encouraging MSMEs to have an identity and legalize their businesses; 3) Ensuring that UMKM players have proof of the legality of their business; 4) Encouraging MSMEs to take care of their business legality; 5) MSME Financing/Capital Facilitation; 6) Cultivate and develop the entrepreneurial spirit of MSMEs; 7) Increase the competitiveness of MSMEs; 8) Creating a conducive business climate for the development of MSMEs; 9) Facilitating UMKM licensing through the implementation of OSS. Entrepreneurs of Micro, Small and Medium Enterprises as actors of economic development in the regions need to be empowered through human resource development, capital support, production and productivity, business protection, partnership development, business and marketing networks as well as business legality, especially registration of business licenses through services. Integrated Electronic Business Licensing/Online Single Submission.

The solutions that need to be done include increasing the socialization of Law no. 20 of 2008 concerning UMKM and Perda No. 13 of 2013 concerning Empowerment of MSMEs, as well as Government Regulation Number 24 of 2018 concerning Integrated Electronic Business Licensing Services/Online Single Submission to MSME players. Through socialization and education, it is hoped that MSME actors will grow awareness of having business legality which is useful for business growth and competitiveness.

\section{CONCLUSION}

Fulfilling business legality aspects can increase the growth and competitiveness of MSMEs. The legality aspect that takes into account the interests of the business world (business friendly) needs to be used as a new paradigm. Lack of socialization and education to MSME business actors regarding the obligation to register permits through OSS in Semarang City affects the compliance of MSMEs in managing their business licenses. Micro, Small and Medium Enterprises as one of the actors of economic development in the regions need to be empowered through human resource development, capital support, production and productivity, business protection, partnership development, business networks and marketing as well as strengthening aspects of business legality. 


\section{BIBLIOGRAPHY}

\section{BOOK :}

Adler Haymans Manurung, 2008, Capital for SME Businesses, Gramedia, Jakarta;

Euis Amalia, 2009, Distributive Justice in Islamic Economics Strengthening the Role of MFIs and SMEs in Indonesia, RajaGrafindo Persada, Jakarta;

Satjipto Rahardjo, 1990, Law and Society, Angkasa Publisher, Bandung;

\section{JOURNAL :}

Amin Purnawan, Akhmad Khisni, Siti Ummu Adillah, Legal Counseling for Registration of Micro and Small Business Permits (IUMK) in Semarang City through the Online Single Submission (OSS) System, Indonesian Journal of Community Services, Vol. 2 (1), 2020;

Amin Purnawan, Reconstruction of Justice Value-Based Corporate Income Tax (PPh) System, Journal of Legal Dynamics, Vol. 11 February Special Edition, 2011;

Amin Purnawan, Siti Ummu Adillah, Problems in the Implementation of MSME Business Legality Registration through the Online Single Submission (OSS) System in Semarang City, Unissula Competitive Research Report, 2019;

Amin Purnawan, Kami Hartono, Development of UMKM through Strengthening Aspect of Business Legality (Case Study of Weaving Industry in Central Java), International Journal of Applied Business and Economic Research, Vol. 15 (24), 2017;

Arijanto, A., Financing for the Small and Medium Enterprises Sector. Center for Teaching Material Development-UMB. Module 11 of the Indonesian Economy, no year;

Heru Sulistyo, Siyamtinah, Eni Rahmani, Model of Improving Innovation Capability to Improve SME Performance in Semarang City, Second Year Higher Education Competitive Grant Research Report, 2011;

Rakhmat Bowo Suharto, Regulation Urgency Concerning Administrative Sanction Guidelines in Space Administration, Journal of Legal Reform, Vol. VI No.3, September-December, 2019;

Siyamtinah and Eni Rahmani, Green Business Development Model for Improving Financial Performance and Market Performance, Higher Education Competitive Grant Research Report, 2012;

\section{REGULATION :}

Law Number 20 of 2008 concerning Micro, Small and Medium Enterprises. 
Government Regulation Number 17 of 2013 concerning Implementation of Law Number 20 of 2008 concerning Micro, Small and Medium Enterprises

Government Regulation Number 24 of 2018 concerning Integrated Electronic Business Licensing Services / Online Single Submission (OSS).

Central Java Provincial Regulation Number 13 of 2013 concerning Empowerment of Micro, Small and Medium Enterprises. 